\title{
Analysis of sunflower oil in ternary mixture with grapeseed oil and candlenut oil in the ternary mixture system using FTIR spectroscopy and chemometrics
}

\author{
${ }^{1,2}$ Riyanta, A.B., ${ }^{1}$ Riyanto, S., ${ }^{1}$ Lukitaningsih, E. and ${ }^{1,3}$ Rohman, A. \\ ${ }^{1}$ Department of Pharmaceutical Chemistry, Faculty of Pharmacy, Universitas Gadjah Mada, Yogyakarta \\ ${ }^{2}$ Department of Pharmacy, Politeknik Harapan Bersama, Central Java 52147 Indonesia \\ ${ }^{3}$ Institute of Halal Industry and Systems, Universitas Gadjah Mada, Yogyakarta 55281 Indonesia
}

\begin{abstract}
Article history:
Received: 15 January 2020

Received in revised form: 14

June 2020

Accepted: 18 June 2020

Available Online: 24 June

2020
\end{abstract}

\section{Keywords:}

Discriminant analysis,

Multivariate calibration

Sunflower oil,

Grapeseed oil,

Candlenut oil

DOI:

https://doi.org/10.26656/fr.2017.4(5).023

\section{Introduction}

Candlenut (Aleurites mollucana (L.) willd.) is a plant often found in eastern Indonesia (Sulistyo et al., 2009). Linoleic, oleic acid is a polyunsaturated oil contained in candlenut oil (Imdadul et al., 2017). Due to the unsaturated fatty acid content, candlenut oil (CDNO) is more expensive than other vegetable oil, especially in Indonesian fats industry (Yuliani et al., 2017). Candlenut originates from the Indo-Malaysia region and the productivity of the oil yield obtained from its seed is approximately $3200 \mathrm{~kg} / \mathrm{ha}$ annually (Elevitch and Manner, 2006; Riyanta et al., 2020). Candlenut leave's traditionally used to treat coughs, diarrhea, headaches, ulcers, fever, hernia, and gonorrhoea (Quintãoa et al., 2019), Unfortunately, the seeds of the plant are considered as toxic for oral use (González-Stuart and Rivera, 2003). In addition, candlenut oil extracted from candlenut fruit was applied in the cosmetics industry, as good material for varnish, soap, and other oil-based cosmetics products (Subroto et al., 2017). Grapeseed oil (GSO) is considered as one of the possible sources of special lipids (Fernandes et al., 2013). GSO has a high content of polyunsaturated fatty acids (PUFA) at a range of $85-90 \%$ and among them, linoleic acid is dominant. Linoleic acid is associated with the promotion of cardiovascular health by down-regulating low-density lipoprotein cholesterol (LDL-c). GSO also contains some phytochemical components such as phytosterols, tocopherols, tocotrienols, flavonoids, phenolic acids and carotenoids which are important to human health (Crews et al., 2006).

The analytical methods applied for analysis for oil content are mainly based on chromatographic techniques (Maffei et al., 1992) such as gas chromatography for the analysis of fatty acid composition (Al-Ismail et al., 2011) and high performance liquid chromatography for the analysis of triacylglycerol composition (Rohman et al., 2012). However, this method is time-consuming and needs skillful analyst, therefore, a more rapid and simple analytical method must be developed for quality control of high price oils. One of the emerging methods for the analysis of oils is Fourier transform infrared (FTIR) 
spectroscopy, especially combined with multivariate data analysis (chemometrics). Chemometrics is the application of mathematics and statistics to treat the chemical data including FTIR spectra to be extracted in more information which is easy to understand and is applied widely in the authentication of fats and oils (Rohman and Che Man, 2012).

The combination FTIR spectroscopy with chemometrics has been used for authentication studies of candlenut oil from soybean oil (Yuliani et al., 2017), olive oil from other vegetable oils (Lizhi et al., 2010), and analysis of plant oil in binary mixtures with pyridyl, abamectin, spinosad and malathion (Abd El-Razik and Zayed, 2014). Besides, this technique was also used for the analysis of pumpkin seed oil (Irnawati et al., 2020), analysis of walnut oil in binary mixture of sunflower oil (Ge et al., 2014) and analysis of essential oil (Khudzaifi et al., 2020). The reported publications are mostly on the authentication of high price oil with the lower one in the binary mixture and there are limited studies regarding the use of FTIR spectroscopy for analysis of sunflower in ternary mixtures with other oils. Therefore, this study highlighted the development of FTIR spectroscopy for analysis of sunflower oil in the ternary mixture with grapeseed oil and candlenut oil.

\section{Materials and methods}

\subsection{Materials}

Some oils including Rice bran oil (Oryza grace), aring oil (Lilas), sunflower seed oil (Mazola), pumpkin seed oil (happy green), sesame oil (Lee kum kee), soybean oil (Mazola), grapeseed oil (Borges), extra virgin olive oil (Bertolli), Dayak onion oil (MKR), olive oil (MKR), coconut oil (MKR), cumin oil (MKR), canola oil (MKR), castor oil (MKR), palm oil (sun co), corn oil (Mazola), garlic oil (Double pagoda), cananga oil (MKR), rose oil (MKR), orange oil (MKR), fannel oil (MKR), clove oil (MKR), eucalyptus oil (MKR), peppermint oil (MKR), paraffin liquid (MKR) were used for principal component analysis (PCA). PCA is intended to find the oils having similar FTIR spectra with candlenut oil (CDNO). These oils were obtained from different markets around Yogyakarta. CDNO was purchased from Tegal region, Central Java, Indonesia. The other solvents and reagents were of pro-analytical grade.

\subsection{Preparation of calibration and validation samples}

A total of twenty-nine samples consisting of SFO, GPO and CDNO in ternary mixtures at concentration ranges of $0-100.0 \% \mathrm{v} / \mathrm{v}$ were prepared. The composition of calibration samples were prepared randomly Excel (Microsoft Inc., USA), as shown in Table 1. All samples were analyzed using FTIR spectrophotometer.

Table 1. The composition of sunflower oil (SFO) in ternary mixtures with grapeseed (GPO) and candlenut oil (CDNO)

\begin{tabular}{cccc}
\hline \multirow{2}{*}{ No } & \multicolumn{3}{c}{ Percentage } \\
\cline { 2 - 4 } & SFO & GPO & CDNO \\
\hline 1 & 48 & 24 & 28 \\
2 & 49 & 37 & 14 \\
3 & 28 & 11 & 61 \\
4 & 46 & 10 & 44 \\
5 & 20 & 15 & 65 \\
6 & 2 & 31 & 68 \\
7 & 7 & 40 & 54 \\
8 & 11 & 38 & 51 \\
9 & 26 & 15 & 59 \\
10 & 6 & 36 & 58 \\
11 & 46 & 49 & 5 \\
12 & 31 & 41 & 29 \\
13 & 38 & 0 & 62 \\
14 & 2 & 29 & 69 \\
15 & 41 & 46 & 13 \\
16 & 14 & 40 & 46 \\
17 & 45 & 28 & 27 \\
18 & 23 & 35 & 42 \\
19 & 34 & 23 & 43 \\
20 & 8 & 43 & 49 \\
21 & 49 & 28 & 23 \\
22 & 14 & 46 & 40 \\
23 & 34 & 44 & 22 \\
24 & 33 & 17 & 51 \\
25 & 11 & 31 & 57 \\
\hline & & &
\end{tabular}

\subsection{Discriminant analysis}

Discriminant analysis (DA) was used for discriminating between pure SFO and SFO in ternary mixture with GPO and CDNO. For training set, the authentic CDNO and CDNO added with SFO and GSO in ternary system were prepared at concentration of $0.5-$ $50.0 \%(\mathrm{v} / \mathrm{v})$ of SFO were prepared. Both groups (pure SFO and SFO-GPO-CDNO) were classified and discriminated using DA on the basis of Cooman's plot using FTIR spectral absorbance at specific wavenumbers as variables.

\subsection{FTIR spectra acquisition}

The scanning of FTIR spectra of oil samples were done using the FTIR spectrophotometer (Thermo Scientific Nicolet iS10, Madison, WI), equipped with the Omnic software for spectral processing. Horizontal attenuated total reflectance (HATR) at wavenumbers of $4000-650 \mathrm{~cm}^{-1}$ using thirty-two scans with resolution of 8 $\mathrm{cm}^{-1}$ was applied. Air used as background for all FTIR spectra were corrected against FTIR spectrum. A new reference air background spectrum was taken after every scan. These spectra were recorded as absorbance values at each data point in triplicate. 


\subsection{Chemometrics analysis}

Chemometrics analysis including discriminant analysis and multivariate calibrations of Principle component regression (PCR) and partial least square (PLS) was performed using TQ Analyst software version 9 (Thermo Fisher Scientific, Inc.). Statistical parameters used for the evaluation of multivariate calibrations performance were coefficient of determination $\left(\mathrm{R}^{2}\right)$ and root mean square error of calibration (RMSEC) as well as root mean square error of prediction (RMSEP).

\section{Results and discussion}

Figure 1 shows that the three edible oils, sunflower oil (SFO), grapeseed oil (GPO), and candlenut oil (CDNO) as FTIR-ATR spectra were scanned at midinfrared regions corresponding to wavenumbers of 4000 $650 \mathrm{~cm}^{-1}$. The characteristic peaks in FTIR spectra represented the presence of several functional groups of the compounds. The interpretation of each peak and shoulder in relation to functional groups in FTIR spectra was presented in Table 2. Among SFO, GPO and CDNO spectra are very similar based on all peaks in FTIR-ATR. It's because the main components composing edible fats and oils were triglyceride (95-98\%), glycerol esterified with three fatty acids. However, FTIR-ATR spectra of SFO, GPO and CDNO reveal slight differences upon detailed investigation, in terms of band intensities (absorbances) and the exact wavenumbers in each peak and shoulders.

Two multivariate calibrations performed to quantitative analysis of SFO in ternary mixtures with GPO and CDNO, namely principle component regression (PCR) and partial least square (PLS). PCR is one of inverse calibration in which the concentration ( $\mathrm{x}$ axis) is used as a predictor, while response such as absorbance at several wavelengths is located in the y-
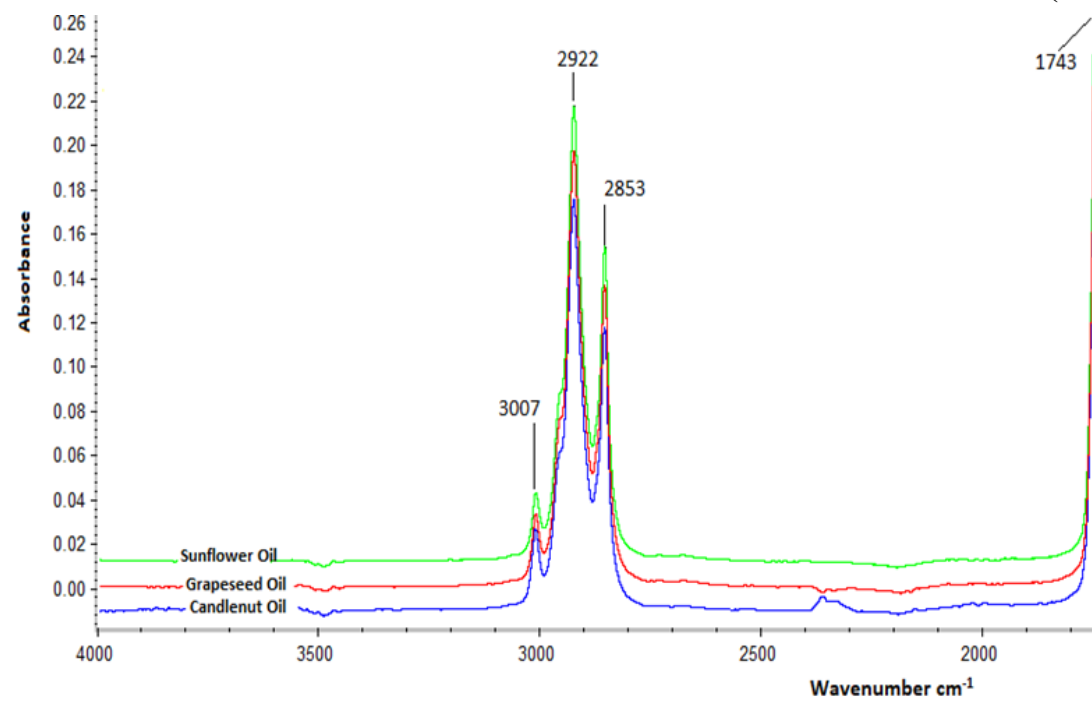

axis. PCR performs multiple inverse calibrations of predictor variables against the scores (knowns as principal components) rather than original variables. PCR uses regression to converts scores of principal components (PCs) into concentration. PCs are obtained during principal component analysis (PCA). PLS is the most reported multivariate calibration for quantitative analysis to solve problems involving high collinearity. The main difference between PCR and PLS is that the first PC or factor in PCR represents the highest variations in the responses, whereas the first PC1 in PLS represents the most relevant variations showing the best correlation with the target property values (Rohman and Putri, 2019).

Table 2. Functional group responsible for absorption of peaks and shoulders in sunflower oil, grapeseed oil, and candlenut oil

\begin{tabular}{ll}
\hline $\begin{array}{c}\text { Wavenumbers region } \\
\left(\mathrm{cm}^{-1}\right)\end{array}$ & \multicolumn{1}{c}{$\begin{array}{c}\text { Functional groups and vibration } \\
\text { modes }\end{array}$} \\
\hline 3007 & cis $\mathrm{C}=\mathrm{CH}$, stretching vibration \\
2922 and 2853 & $\begin{array}{l}\text { methylene }\left(-\mathrm{CH}_{2}\right) \text {, asymmetric and } \\
\text { symmetric stretching vibrations }\end{array}$ \\
1743 & carbonyl $(\mathrm{C}=\mathrm{O})$, stretching vibration \\
1654 & $\mathrm{C}=\mathrm{C}$, stretching vibration \\
1460 & methylene $\left(-\mathrm{CH}_{2}\right)$, bending vibration \\
1376 & methyl $\left(-\mathrm{CH}_{3}\right)$, bending vibration \\
$1237,1158,1116,1097$ & $\mathrm{C}-\mathrm{O}$, stretching vibrations \\
996 & $-\mathrm{HC}=\mathrm{CH}-($ trans $)$, bending out of \\
850 and 721 & plane \\
\hline
\end{tabular}

Table 3 presents the performance of PCR and PLS for prediction of SFO in ternary mixtures with GPO and CDNO along with wavenumbers regions and FTIR spectral modes used (normal and derivatives). Based on the variation existed, the wavenumbers regions were selected among SFO, GPO, and CDNO. In addition, derivatization was intended to resolve any extensive overlapping peaks. The selection of FTIR spectroscopy conditions (multivariate calibrations, spectral modes, and

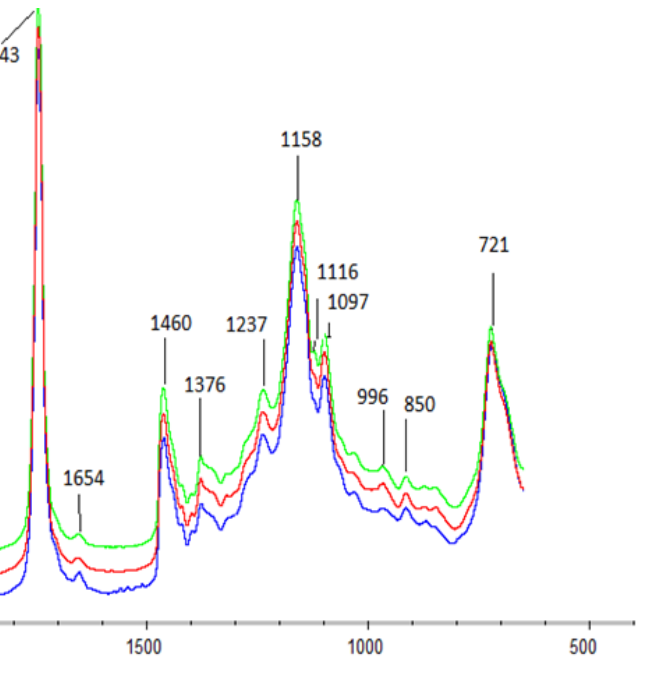

Figure 1. FTIR spectra using attenuated total reflectance mode of sunflower, grapeseed oil, and pumpkin candlenut oil acquired at mid-infrared region $\left(4000-650 \mathrm{~cm}^{-1}\right)$ 
Table 3. The performance of principle component regression (PCR) and partial least square (PLS) for prediction of sunflower in ternary mixtures with grapeseed oil and candlenut oil along with wavenumbers regions and FTIR spectral modes used (normal and derivatives).

\begin{tabular}{|c|c|c|c|c|c|c|}
\hline \multirow{2}{*}{$\begin{array}{l}\text { Multivariate } \\
\text { calibrations }\end{array}$} & \multirow{2}{*}{$\begin{array}{l}\text { Wavenumber } \\
\left(\mathrm{cm}^{-1}\right)\end{array}$} & \multirow{2}{*}{ Spectra } & \multicolumn{2}{|c|}{ Calibration } & \multicolumn{2}{|c|}{ Validation } \\
\hline & & & $\mathrm{R}$ & RMSEC & $\mathrm{R}$ & RMSEP \\
\hline \multirow[t]{15}{*}{ PCR } & \multirow[t]{3}{*}{$4000-650$} & Normal & 0.9536 & 4.77 & 0.8217 & 9.28 \\
\hline & & derivative 1 & 0.9561 & 4.65 & 0.8473 & 8.68 \\
\hline & & derivative 2 & 0.9234 & 6.09 & 0.8258 & 9.7 \\
\hline & \multirow{3}{*}{$\begin{array}{l}3000-2800 \text { and } \\
1600-650\end{array}$} & Normal & 0.9451 & 5.18 & 0.8713 & 8.07 \\
\hline & & derivative 1 & 0.9429 & 5.28 & 0.8613 & 8.28 \\
\hline & & derivative 2 & 0.9139 & 6.44 & 0.8219 & 9.28 \\
\hline & \multirow[t]{3}{*}{$3100-2750$} & Normal & 0.9644 & 4.19 & 0.8755 & 7.87 \\
\hline & & derivative 1 & 0.9763 & 3.44 & 0.8943 & 7.65 \\
\hline & & derivative 2 & 0.9715 & 3.76 & 0.887 & 7.72 \\
\hline & \multirow[t]{3}{*}{$3050-2800$} & Normal & 0.9402 & 5.4 & 0.8538 & 8.79 \\
\hline & & derivative 1 & 0.9531 & 4.8 & 0.8427 & 8.6 \\
\hline & & derivative 2 & 0.9319 & 5.75 & 0.8102 & 9.5 \\
\hline & \multirow[t]{3}{*}{$1800-650$} & Normal & 0.9536 & 4.77 & 0.8217 & 9.28 \\
\hline & & derivative 1 & 0.9561 & 4.65 & 0.8473 & 8.68 \\
\hline & & derivative 2 & 0.9234 & 6.09 & 0.8258 & 9.7 \\
\hline \multirow[t]{15}{*}{ PLS } & \multirow[t]{3}{*}{$4000-650$} & Normal & 0.939 & 5.46 & 0.7495 & 10.6 \\
\hline & & derivative 1 & 0.9993 & 0.58 & 0.8686 & 8.12 \\
\hline & & derivative 2 & 0.9947 & 1.63 & 0.8786 & 8.53 \\
\hline & \multirow{3}{*}{$\begin{array}{l}3000-2800 \text { and } \\
1600-650\end{array}$} & Normal & 0.972 & 3.72 & 0.87 & 8.05 \\
\hline & & derivative 1 & 0.9715 & 3.76 & 0.8802 & 7.82 \\
\hline & & derivative 2 & 0.9918 & 2.02 & 0.8581 & 8.43 \\
\hline & \multirow[t]{3}{*}{$3100-2750$} & Normal & 0.926 & 5.99 & 0.9084 & 7.15 \\
\hline & & derivative 1 & 0.9933 & 1.83 & 0.8981 & 7.28 \\
\hline & & derivative 2 & 0.9999 & 0.233 & 0.8744 & 7.9 \\
\hline & \multirow[t]{3}{*}{$3050-2800$} & Normal & 0.9732 & 3.65 & 0.8771 & 7.86 \\
\hline & & derivative 1 & 0.989 & 2.34 & 0.8455 & 8.58 \\
\hline & & derivative 2 & 0.9749 & 3.53 & 0.8006 & 9.76 \\
\hline & \multirow[t]{3}{*}{$1800-650$} & Normal & 0.939 & 5.46 & 0.7495 & 10.6 \\
\hline & & derivative 1 & 0.9993 & 0.58 & 0.8686 & 8.12 \\
\hline & & derivative 2 & 0.9947 & 1.63 & 0.8786 & 8.53 \\
\hline
\end{tabular}

Bold indicates selected variables. $\mathrm{R}=$ correlation coefficient; $\mathrm{RMSEC}=$ root mean square error of prediction; RMSEP $=$ root mean square error of prediction.

wavenumbers regions) was based on the highest coefficient of correlation (R) and the lowest errors in calibration and prediction, expressed with root mean square error of calibration (RMSEC) and root mean square error of prediction (RMSEP). Finally, the second derivative FTIR spectra at the wavenumbers regions of $3100-2750 \mathrm{~cm}^{-1}$ aided with PLS regression offered the best prediction models for quantitative analysis of SFO in ternary mixtures with GPO and CDNO. The R values obtained for the correlation between actual values and FTIR predicted values were 0.9999 and 0.874 in calibration and validation models, while RMSEC and RMSEP values were $0.233 \%$ and $7.90 \%$, respectively (Figure 2). The low errors either in calibration and prediction models were confirmed by residual analysis in which no systematic errors were observed. The high $\mathrm{R}$ values and lowest values of RMSEC and RMSEP indicated that FTIR spectroscopy aided with PLS offered a reliable technique for analysis of SFO. This results could be extended for analysis of SFO as adulterants in high valuable oils such as GPO and CDNO either in binary or ternary models.

Discriminant analysis (DA), one of the supervised pattern recognition techniques, was used for discrimination between pure SFO and SFO in ternary mixtures with GPO and CDNO. Both classes (pure and the mixture) were clearly separated indicating that SFO was different from GPO and CDNO (Figure 3). The accuracy levels of discrimination capacity were $100 \%$, meaning that no training samples were misclassified in the wrong groups. Misclassification may occur if both 
groups are very similar. This result could be extended that DA based on Mahalanobis distance of variables used (absorbances at wavenumbers of $3100-2750 \mathrm{~cm}^{-1}$ ) was an effective means for authentication of GPO and CDNO from the possible adulteration with low-value edible oils such as sunflower oil.

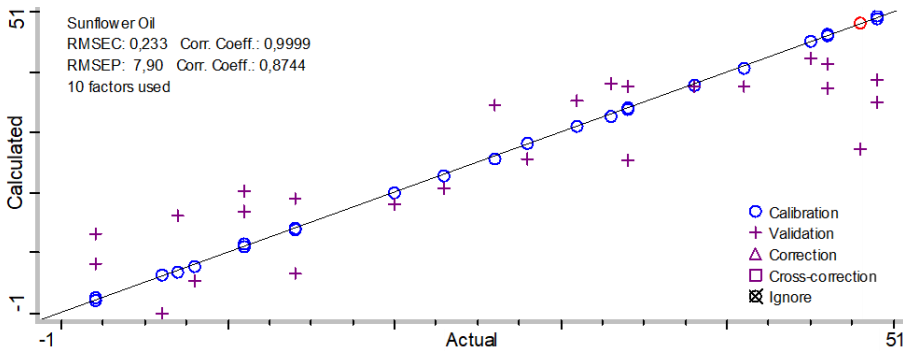

Figure 2. The correlation between actual values (x-axis) and FTIR predicted values (y-axis) of sun flower oil in ternary mixtures with grapeseed oil (GPO) and candlenut oil (CDNO) with coefficient correlation of 0.9999 and 0.8744 in calibration and validation models. RMSEC $=$ root mean square error of calibration; RMSEP = root mean square error of prediction.

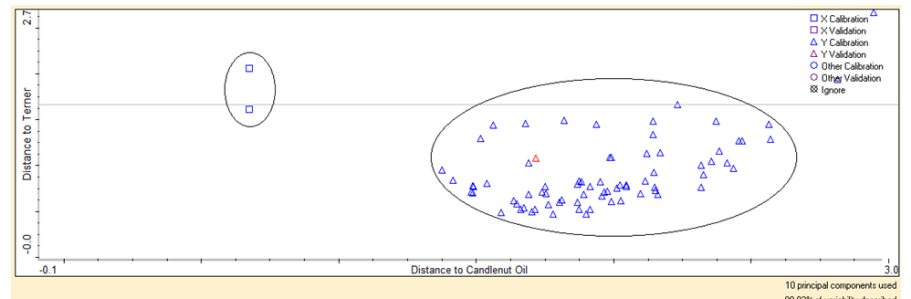

Figure 3. The discriminant analysis expressed by Cooman's plot for the discrimination of sunflower and sunflower oils in ternary mixtures with grapeseed oil and candlenut oil.

\section{Conclusion}

Fourier transform infrared (FTIR) spectroscopy combined with PLS using second derivative FTIR-ATR spectra at the wavenumber's regions of $3100-2750 \mathrm{~cm}^{-1}$ is capable of quantifying sunflower oil in ternary mixtures with grapeseed oil and candlenut oil. In addition, discriminant analysis is also successfully used for classifying SFO and SFO in ternary mixture with grapeseed oil and candlenut oil. The developed method is reliable and is suitable to be used for authentication analysis of high price oils (candlenut oil and grapeseed oil from potential adulterant).

\section{Conflict of interest}

The authors declare no conflict of interest.

\section{Acknowledgement}

The authors thank to Universitas Gadjah Mada, Yogyakarta Indonesia for financial support during this research via the scheme Rekognisi Tugas Akhir year 2019 awarded to Prof. Dr. Abdul Rohman with contract number of 2129/UN1/DITLIT/DIT-LIT/LT/2019.

\section{References}

Al-Ismail, K.M., Alsaed, A.K., Ahmad, R. and AlDabbas, M. (2010). Detection of olive oil adulteration with some plant oils by GLC analysis of sterols using polar column. Food Chemistry, 121(4), 1255-1259.

https://doi.org/10.1016/

j.foodchem.2010.01.016

Crews, C., Hough, P., Godward, J., Brereton, P., Lees, M., Guiet, S. and Winkelmann, W. (2006). Quantitation of the main constituents of some authentic grape-seed oils of different origin. Journal of Agricultural and Food Chemistry, 54(17), 62616265. https://doi.org/10.1021/jf060338y

Abd El-Razik, M.A.A. and Zayed, G.M.M. (2014). Effectiveness of Three Plant Oils in Binary Mixtures with Pyridalyl, Abamectin, Spinosad and Malathion against Callosobruchus maculatus (F.) Adults. American Journal of Biochemistry and Molecular Biology, 4(2), 76-85. https:// doi.org/10.3923/ajbmb.2014.76.85

Elevitch, C.R. and Manner, H.I. (2006). Traditional tree initiative: species profiles for Pacific islands agroforestry-ecological, economic, and cultural renewal. Retrieved on December 12, 2019 from Agroforestry website: http://www.agroforestry.net/ tti/Aleurites-kukui.pdf, 2006.

Fernandes, L., Casal, S., Cruz, R., Pereira, J.A. and Ramalhosa, E. (2013). Seed oils of ten traditional Portuguese grape varieties with interesting chemical and antioxidant properties. Food Research International, 50(1), 161-166. https:// doi.org/10.1016/j.foodres.2012.09.039

Ge, F., Chen, C., Liu, D. and Zhao, S. (2014). Rapid quantitative determination of walnut oil adulteration with sunflower oil using fluorescence spectroscopy. Food Analytical Methods, 7, 146-150. https:// doi.org/10.1007/s12161-013-9610-z

Imdadul, H.K., Zulkifli, N.W.M., Masjuki, H.H., Kalam, M.A., Kamruzzaman, M., Rashed, M.M. and Alwi, A. (2017). Experimental assessment of non-edible candlenut biodiesel and its blend characteristics as diesel engine fuel. Environmental Science and Pollution Research, 24(3), 2350-2363. https:// doi.org/10.1007/s11356-016-7847-y

Irnawati, Riyanto, S., Martono, S. and Rohman, A. (2020). The employment of FTIR spectroscopy and chemometrics for authentication of pumpkin seed oil from sesame oil. Food Research, 4(1), 42-48. https://doi.org/10.26656/fr.2017.4(1).198

Khudzaifi, M., Retno, S.S. and Rohman, A. (2020). The employment of FTIR spectroscopy and chemometrics for authentication of essential oil of 
Curcuma mangga from candle nut oil. Food Research, 4(2), 515-521 https://doi.org/10.26656/ fr.2017.4(2).313

Lizhi, H., Toyoda, K. and Ihara, I. (2010). Discrimination of olive oil adulterated with vegetable oils using dielectric spectroscopy. Journal of Food Engineering, 96(2), 167-171. https:// doi.org/10.1016/j.jfoodeng.2009.06.045

Maffei, M., Peracino, V. and Sacco, T. (1992). Multivariate methods for aromatic plants: an application to mint essential oils. ISHS Acta Horticulturae, 330, 159-170. https:// doi.org/10.17660/ActaHortic.1993.330.18

Quintãoa, N.M., Pastor, M.V.D., de-Souza Antonialli, C., da Silva, G.F., Rocha, L.W., Berté, T.E., Souza, M.M.D., Meyre-Silva, C., Lucinda-Silva, R.M., Bresolin, T.M.B. and Filho, V.C. (2019). Aleurites moluccanus and its main active constituent, the flavonoid 2"-Orhamnosylswertisin, in experimental model of rheumatoid arthritis. Journal of Ethnopharmacology, 235, 248-254. https:// doi.org/10.1016/j.jep.2019.02.014

Riyanta, A.B., Riyanto, S., Lukitaningsih, E. and Rohman, A. (2020). The employment of Fourier Transform Infrared Spectroscopy (FTIR) and chemometrics for analysis of candlenut oil in binary mixture with grapeseed oil. Food Research, 4(1), 184-190. https://doi.org/10.26656/fr.2017.4(1).279

Rohman, A., Triyana, K., Sismindari and Erwanto, Y. (2012). Differentiation of lard and other animal fats based on triacylglycerols composition and principal component analysis. International Food Research Journal, 19(2), 475-479.

Rohman, A. and Che Man, Y.B. (2012). The chemometrics approach applied to FTIR spectral data for analysis of rice bran oil in extra virgin olive oil. Chemometrics and Intelligent Laboratory Systems, 110(1), 129-134. https://doi.org/10.1016/ j.chemolab.2011.10.010

Rohman, A. and Putri, A.R. (2019). The Chemometrics Techniques in Combination with Instrumental Analytical Methods Applied in Halal Authentication Analysis. Indonesian Journal of Chemistry, 19(1), 262 - 272. https://doi.org/10.22146/ijc.28721

Subroto, E., Widjojokusumo, E., Veriansyah, B. and Tjandrawinata, R.R. (2017). Supercritical $\mathrm{CO}_{2}$ extraction of candlenut oil: process optimization using Taguchi orthogonal array and physicochemical properties of the oil. Journal of Food Science and Technology, 54, 1286-1292. https://doi.org/10.1007/ s13197-017-2542-7

Sulistyo, H., Rahayu, S.S., Suardjaja, I.M. and Setiadi,
U.H. (2009). Crude candlenut oil ethanolysis to produce renewable energy at ambient condition presented at the Proceedings of the World Congress on Engineering and Computer Science, October 2022, 2009. San Francisco, USA.

Yuliani, F., Riyanto, S. and Rohman, A. (2018). Application of FTIR spectra combined with chemometrics for analysis of candlenut oil adulteration. International Journal of Applied Pharmaceutics, 10(5), 54-59. https:// doi.org/10.22159/ijap.2018v10i5.28372 